\title{
Island Berth Untuk Kapal Tanker 85000 DWT Loading Oil Product: BBM Ron 85 Tersus PT. Badak NGL Bontang
}

\author{
Adita Utami ${ }^{\text {a* }}$, Cahya Buana ${ }^{a}$, Fuddoly $^{\mathrm{a}}$, \\ ${ }^{a}$ Departemen Teknik Sipil, FTSP, Institut Teknologi Sepuluh Nopember (ITS), Kampus ITS, Sukolilo, Surabaya 60111, Indonesia
}

\begin{abstract}
Abstrak
Seiring dengan peningkatan permintaan Bahan Bakar Minyak (BBM) jenis premium yang diprediksi oleh BUMN minyak dan gas (MIGAS) sebesar 31 juta kiloliter dimulai dari tahun 2013, maka PT. Pertamina (Persero) berencana untuk meningkatkan kapasitas kilang-kilang minyak yang ada dengan cara melakukan pengembangan untuk kilang baru yang akan diletakkan pada area offshore PT. Badak NGL Bontang. Kilang tersebut direncanakan mengalami penambahan kapasitas produksi sebesar 200.000 barel/hari. Untuk mendukung peningkatan kegiatan produksi dan pengiriman Bahan Bakar Minyak Premium diperlukan adanya suatu dermaga yang dapat melayani peningkatan arus bongkar muat minyak yang akan meningkat seiring dengan peningkatan produksi. Dermaga Island Berth yang direncanakan adalah dermaga minyak untuk kapal tanker dengan kapasitas 85000 DWT. Perencanaan dermaga baru ini telah diwujudkan dalam bentuk gambar rencana pengembangan dermaga. Namun untuk mewujudkan pembangunan dermaga tersebut diperlukan detail engineering desain yang meliputi perencanaan loading platform, breasting dolphin, mooring dolphin, catwalk, dan floating pontoon. Selain detail engineering desain perlu juga ditinjau kebutuhan kedalaman perairan pada area dermaga Island Berth, hal ini dikarenakan kedalaman perairan harus mencukupi draft dari kapal 85.000 DWT yang direncanakan akan bersandar di dermaga minyak PT. Pertamina (Persero). Pengerjaan konstruksi dermaga Island Berth sepenuhnya dilakukan di laut, sehingga dalam pengerjaannya digunakan kapal pontoon sebagai direksi kit. Perencanaan dermaga Island Berth ini mencakup perencanaan fasilitas laut, perencanaan struktur dermaga, dan perencanaan alat-alat yang digunakan untuk proses bongkar muat. Selain itu perlu juga direncanakan terkait metode pelaksanaan pembangunan yang akan digunakan dalam pembangunan dermaga tersebut. Dalam perencanaan dermaga juga harus ditinjau terkait rencana anggaran biaya dari dermaga tersebut. Dari hasil analisis perhitungan didapatkan kebutuhan dermaga dengan ketentuan Loading Platform sebesar 35,5 x 24 m2, Breasting dolphin 8 x 8 m2, Mooring Dolphin 6,5 x $6,5 \mathrm{~m} 2$,Catwalk dengan panjang 24, 28, dan 30 meter, dan struktur floating pontoon.
\end{abstract}

Keywords: Dermaga Island Berth, Kapal Tanker 85000 DWT.

\section{Pendahuluan}

\subsection{Latar Belakang}

Bontang merupakan salah satu kota di provinsi Kalimantan Timur yang letaknya $120 \mathrm{~km}$ dari pusat kota Samarinda. Secara geografis, kota Bontang terletak pada $0.137^{\circ}$ LU dan $117.5^{\circ}$ BT dan berbatasan langsung dengan kabupaten Kutai Timur. Bontang dikenal sebagai kota industri, jasa, serta perdagangan. Hal ini dibuktikan dengan berdirinya tiga perusahaan besar yaitu : Badak LNG Bontang bergerak di bidang pengolahan gas alam, Pupuk Kalimantan Timur bergerak dibidang industri pupuk dan ammonia, serta Indomico Mandiri bergerak dibidang pertambangan batu bara.

PT. Pertamina (Persero) merupakan sebuah perusahaan BUMN yang bertugas mengelola penambangan minyak dan gas bumi di Indonesia. Pertamina memiliki kilang minyak yang berlokasi di kota Bontang. Kilang minyak yang dimiliki memiliki kapasitas 100 ribu barrel perharinya. Pada tahun 2008 kebutuhan BBM dalam negeri mencapai 1,1 juta barrel per hari sedangkan produksi bahan bakar minyak (BBM) jenis premium dari seluruh kilang minyak di Indonesia hanya 740 ribu barrel perhari. Dari total kebutuhan BBM tersebut, Indonesia mengalami defisit sebesar 360 ribu barrel per harinya yaitu sekitar 33 persen dari 100 persen total kebutuhan BBM. Seiring dengan peningkatan permintaaan Bahan Bakar Minyak (BBM) jenis premium yang diprediksi oleh pemerintah sebesar 31 juta kiloliter pada tahun 2013, pemerintah bersama PT. Pertamina berencana untuk meningkatkan kapasitas kilang-kilang minyak yang ada dengan cara melakukan pengembangan untuk kilang baru yang akan diletakkan pada area offshore PT. Badak NGL Bontang. Kilang tersebut direncanakan mengalami penambahan kapasitas produksi sebesar 200.000 barel/hari. Sehingga untuk mendukung peningkatan kegiatan produksi dan pengiriman Bahan Bakar Premium diperlukan adanya suatu dermaga yang dapat melayani peningkatan arus bongkar muat minyak yang akan meningkat seiring dengan peningkatan produksi.

Dengan adanya kapasitas besar yang perlu diproduksi dan ditampung, maka diperlukan suatu alat transportasi laut yang mampu mendistribusikan bahan bakar minyak jenis premium dalam jumlah besar. Untuk itu, digunakan kapal khusus bahan bakar minyak jenis premium berukuran 85000 DWT yang melayani rute pelayaran keluar masuk daerah industri di Bontang, sehingga harus direncanakan dermaga khusus yang bisa melayani kapal jenis ini.

Untuk meningkatkan kapasitas produksi tersebut PT. NGL Bontang merencanakan untuk menggunakan kapal 85.000 DWT. Dengan adanya pembangunan dermaga chargo bahan bakar premium yang kuat, stabil, dan ekonomis diharapkan pemerintah 
bersama PT. Pertamina dapat meningkatkan pelayanan kepada masyarakat Indonesia dengan cara menambah produksi dan supply bahan bakar minyak jenis premium ke seluruh pelosok Indonesia.

\subsection{Perumusan Masalah}

1. Diperlukan pengembangan pelabuhan berupa dermaga Island Berth chargo minyak bahan bakar premium akibat adanya peningkatan produksi dan arus bongkar muat

2. Bagaimana merencanakan dermaga yang terletak di area offshore Terminal Khusus PT. Badak NGL Bontang yang mampu menahan kombinasi pembebanan yang bekerja pada struktur.

3. Diperlukan penyusunan metode pelaksanaan pembangunan dermaga yang lengkap disertai dengan Rencana Anggaran Biaya yang dibutuhkan.

\subsection{Lingkup Perencanaan}

1. Evaluasi layout perairan dan daratan

2. Perencanaan detail struktur dermaga chargo bahan bakar minyak (curah cair) meliputi : Loading platform,breasting dolphin, mooring dolphin, catwalk, dan floating pontoon

3. Metode Pelaksanaan dermaga

4. Analisis Anggaran Biaya

\subsection{Batasan Masalah}

1. Tidak menganalisis gelombang dikarenakan Bontang merupakan area terlindung

2. Tidak menghitung pengerukan dan reklamasi

3. Tidak menganalisis alur pelayaran / SPM

4. Pembahasan hanya dikhususkan pada perencanaan layout perairan dan dermaga, perencanaan struktur dermaga meliput, Loading platform, breasting dolphin dan mooring dolphin, catwalk, dan floating pontoon, perencanaan metode pelaksanaan

\subsection{Lokasi Perencanaan}

Dermaga Island Berth berlokasi di area PT. NGL Badak Bontang Kalimantan Timur pada koordinat $0^{\circ} 5$ ' $25.20^{\prime \prime}$ N $117^{\circ}$ 30’ 29.21" E. Lokasi perencanaan dermaga Island Berth ini secara lengkap dapat dilihat pada gambar 1.1

a)

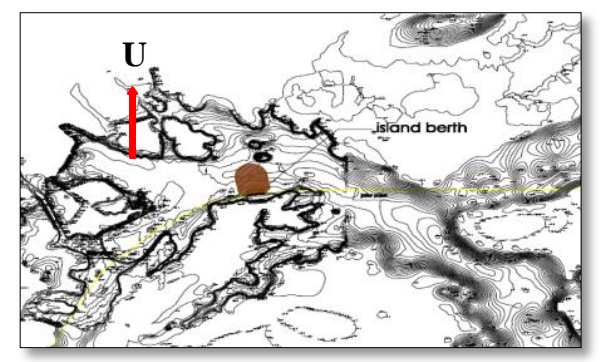

b)

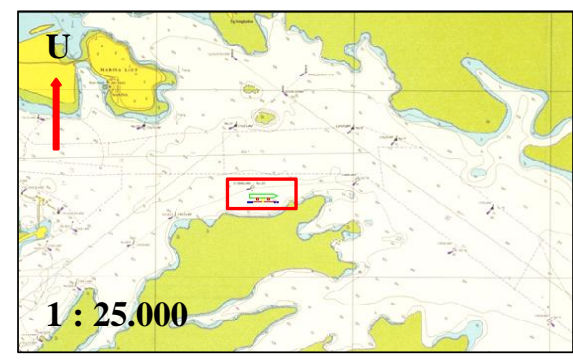

Gambar 1.1 (a) Lokasi perencanaan dermaga (b) Rencana pengembangan dermaga (sumber : Dishidros 2010)

\subsection{Metodologi}

Metodologi perencanaan dermaga Island Berth dapat dilihat pada gambar 1.2 


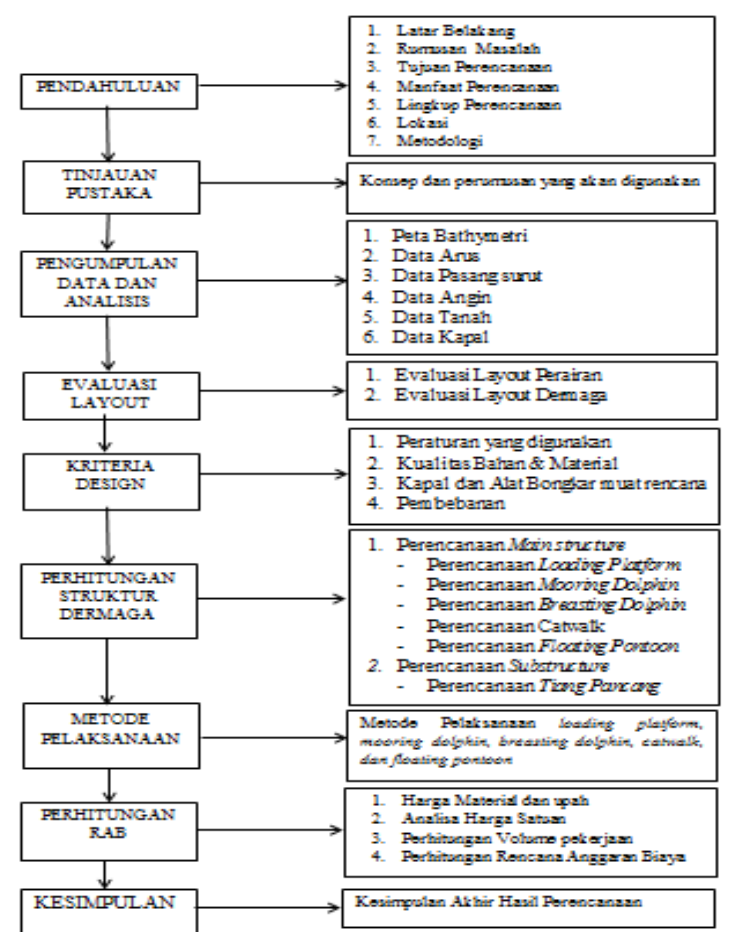

Gambar 1. 2 - Langkah-langkah perencanaan

\section{Pembahasan}

\subsection{Pengumpulan dan Analisis Data}

\section{Data Bathymetri}

Hasil pengukuran bathimetri menunjukkan kondisi kedalaman di sekitar wilayah perairan Dermaga Island Berth Bontang $12.5 \mathrm{~m}$ dari tepi perairan menunjukan kedalaman - 9 mLWS sampai jarak sekitar $36 \mathrm{~m}$ dari daratan semakin dalam sampai pada kedalaman -12.00 mLWS. Peta kontur perairan dan potongan pada gambar a dan $\mathrm{b}$.

a)

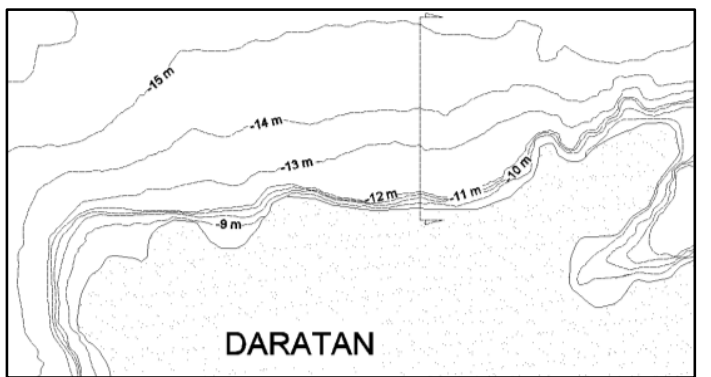

b)

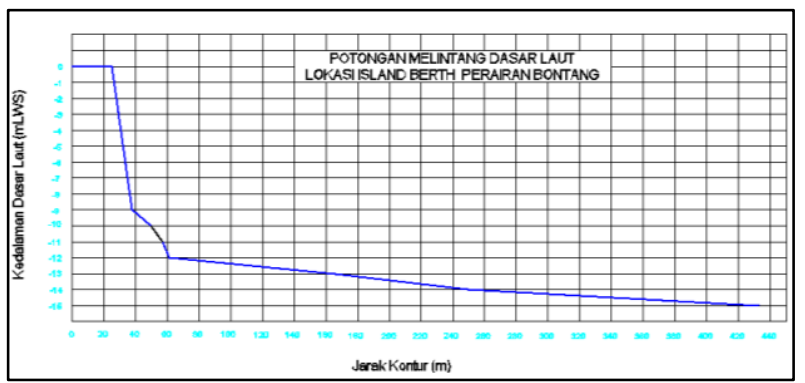

Gambar 2.1 - a) Peta Kontur Area Island Berth, b) Potongan Melintang

( Sumber : Hasil analisis)

\section{Data Pasang Surut.}

Data pasang surut yang diperoleh, digunakan untuk kebutuhan perencanaan gaya horizontal, elevasi dermaga dan kedalaman dermaga. High water level (HWL) selama 31 hari pengamatan adalah +2.46 meter. Kurva hasil rekaman pasang surut di Perairan Bontang ditunjukkan pada Gambar 2.2. 


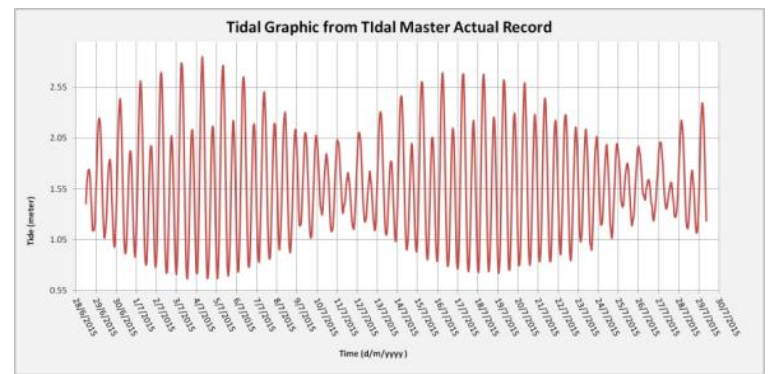

Gambar 2.2 - Grafik pengukuran pasang surut di stasiun pasang surut Sekambing ( Sumber : TimInterim Report ITS)

\section{Data Arus.}

Berdasarkan data arus bulan Januari dan Agustus dapat disimpulkan bahwa kondisi arus pada lokasi Island Berth secara dominan mengarah timur dan barat dengan kecepatan antara 0.00-0.10 m/dt. Sehingga dari analisis data disimpulkan bahwa arah arus tidak mengganggu navigasi kapal karena tidak terjadi cross current dan kecepat arus tidak melebihi dari kecepatan arus yang diizinkan yaitu 3 knots $(1.5 \mathrm{~m} / \mathrm{s})[1]$.

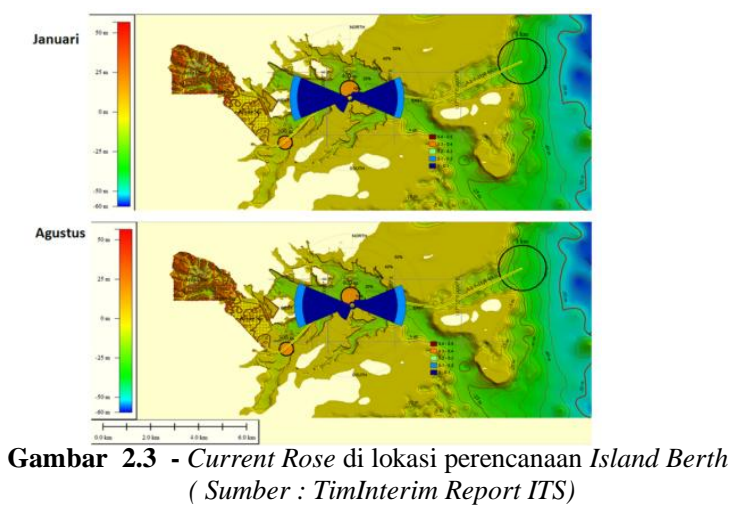

4. Data Angin

( Sumber : TimInterim Report ITS)

Data angin yang diperoleh berupa windrose serta tabel distribusi frekuensi dari arah dan kecepatan angin dalam 8 arah utama (Utara, Timur Laut, Timur, Tenggara, Selatan, Barat Daya, Barat dan Barat laut) per bulan selama 10 tahun. Kemudian data - data tersebut di rata - rata sehingga didapatkan data angin rata - rata per bulan selama 10 tahun. Data tersebut dapat dilihat pada Tabel 2.4.

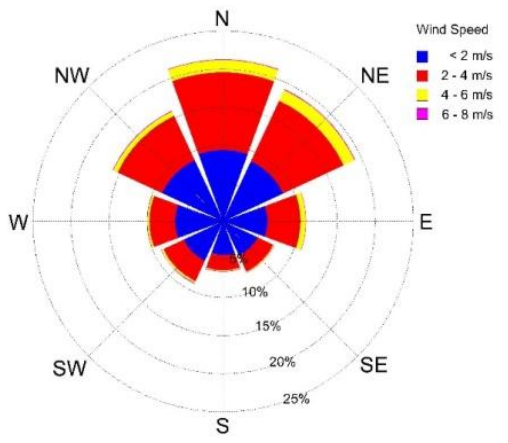

Gambar 2.4 - Windrose Perairan Bontang ( Sumber : LPPM ITS Surabaya yang telah diolah)

\section{Data Tanah}

Penyelidikan data tanah bertujuan untuk merencanakan struktur bagian bawah dermaga. Penyelidikan yang dilakukan pada tanah pada lokasi perencanaan terdiri dari dua tahap yaitu penyelidikan lapangan dan analisa laboratoriumPada perhitungan daya dukung tanah menggunakan metode Luciano Decourt [2]. Rumusan untuk menentukan nilai daya dukung tanah maksimum sebagai berikut :

Dimana :

$$
\mathbf{Q} \mathbf{l}=\mathbf{Q p}+\mathbf{Q s}
$$

$\mathrm{Ql}=$ daya dukung tanah maksimum (ton)

$\mathrm{Qp}=$ resistance ultime di dasar pondasi (ton)

$\mathrm{Qs}=$ resistance ultime akibat lekatan lateral (ton)

Daerah Island Berth memiliki variasi tanah yang memadai, tetapi pada umumnya jenis tanah pada kedalaman -12 sampai $29 \mathrm{mLWS}$ adalah clayed silt, pada $-54 \mathrm{mLWS}$ sampai $-60 \mathrm{mLWS}$ adalah clayey silt with minor sand dengan nilai rata rata 
NSPT 28. Grafik hasil analisasis N-SPT dapat dilihat pada gambar 2.5

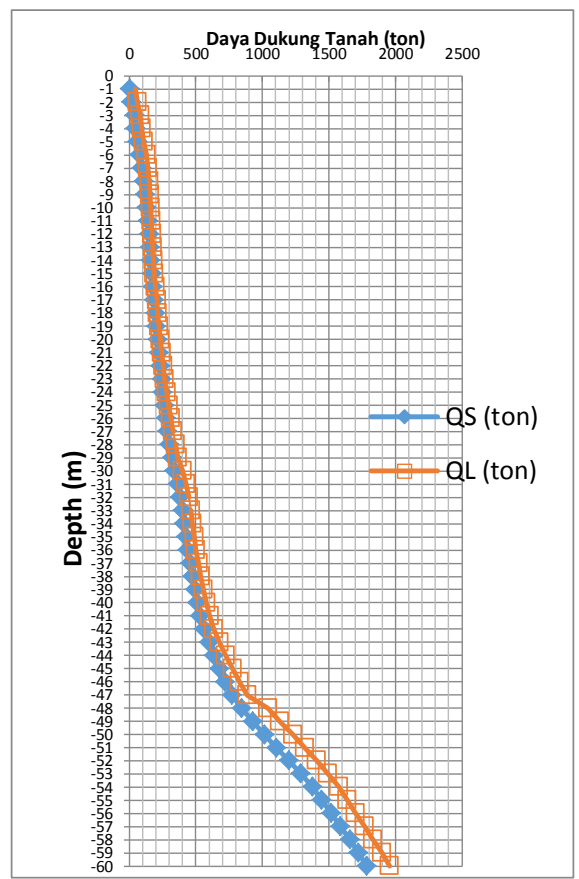

Gambar 2.5 - Grafik hasil analisis N-SPT

\subsection{Evaluasi Layout}

1. Evaluasi Layout Perairan

Berdasarkan hasil perhitungan dan analisis layout perairan yang kemudian ditabelkan pada Tabel 2.1, dan digambarkan pada gambar 2.6.

Tabel 2.1 - Hasil Perhitungan perencanaan layout perairan

\begin{tabular}{lll}
\hline Rencana & Uraian & Dimensi \\
\hline Alur Masuk & Kedalaman & $15 \mathrm{~m}$ \\
& Panjang & $726 \mathrm{~m}$ \\
\multirow{3}{*}{ Turning Basin } & Lebar & $242 \mathrm{~m}$ \\
& Kedalaman & $15 \mathrm{~m}$ \\
Kolam Dermaga & Diameter & $490 \mathrm{~m}$ \\
& Kedalaman & $15 \mathrm{~m}$ \\
& Panjang & $310 \mathrm{~m}$ \\
& Lebar & $45 \mathrm{~m}$ \\
\hline
\end{tabular}

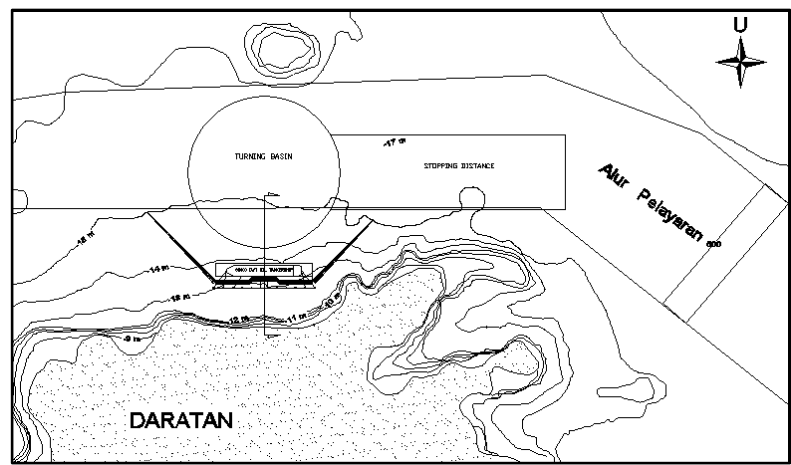

Gambar 2.6 - Layout hasil evaluasi perencanaan layout perairan 
2. Evaluasi Layout Daratan

- Dimensi Sturktur

Ukuran loading Platform

Ukuran Breasting Dolpin

$=35,5 \times 24$ meter

$=6,5 \times 6,5$ meter

Ukuran Mooring Dolphin

$=4 \times 4$ meter

Lebar Catwalk

Ukuran Floating Pontoon

$=1,5$ meter

$=62,5 \mathrm{~m}^{2}$

- Elevasi Struktur

$\mathrm{H}=\mathrm{HWS}+(0.5-1.5 \mathrm{~m})$

Elevasi loading Platform

$=3,96$ meter

$=4,46$ meter

Elevasi Breasting Dolpin

$=4,46$ meter

Elevasi Mooring Dolphin

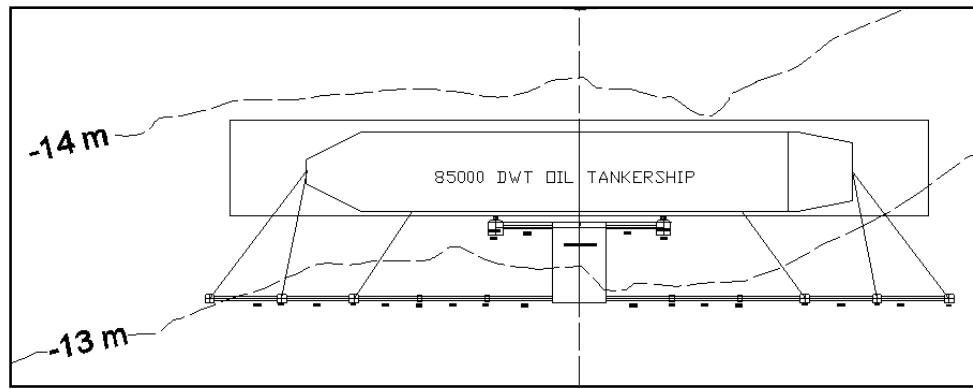

Gambar 2.7 - Hasil evaluasi layout sisi daratan dermaga Island Berth

\section{$2.3 \quad$ Kriteria Desain}

1. Kriteria kapal rencana

Dalam tugas akhir ini kapal tanker minyak yang direncanakan untuk bertambat di dermaga Island Berth PT. Badak NGL adalah kapal tanker BBM premium 85.000 DWT seperti pada gambar 2.8 dengan spesifikasi sebagai berikut :
a. DWT
$=85.000$ ton
b. Displacement Tonnage
$=120.000$ ton
c. GT (Gross Tonnage)
$=47.005$ ton
d. Loa (Length Overall)
$=242 \mathrm{~m}$
e. Lbp
f. B (Beam)
$=230 \mathrm{~m}$
$=35,4 \mathrm{~m}$
g. d (full Draft)
$=12,92 \mathrm{~m}$
$=4,27 \mathrm{~m}$
$=20,12 \mathrm{~m}$
i. Tinggi kapal
$=20,12 \mathrm{~m}$
$=133.024 \mathrm{~m}^{3}$
j. Kapasitas

2. Kualitas bahan dan material

- Mutu beton K350

Kuat tekan karateristik K350

$\mathrm{Eb} \quad=6400 \sqrt{3} 50 \mathrm{~kg} / \mathrm{cm}^{-2}$

$\mathrm{N} \quad=\mathrm{E}_{\mathrm{a}} / \mathrm{E}_{\mathrm{b}}=2,110^{6} / 1,19710^{5}$

$\bar{\sigma}_{b^{\prime}} \quad=1 / 3 \sigma_{\mathrm{bk}}=1 / 3 \times 350$

$=350 \mathrm{~kg} / \mathrm{cm}^{2}$

$=1.197 \times 10^{5} \mathrm{~kg} / \mathrm{cm}^{-2}$

$=17,54$

$=115.5 \mathrm{~kg} / \mathrm{cm}^{2}$

- Mutu Baja Tulangan U32

Tegangan putus $\sigma_{\mathrm{a}}$

Tegangan tarik/tekan baja $\sigma_{\text {au }}$

Ea

$=1850 \mathrm{~kg} \cdot \mathrm{cm}^{-2}$

$=2780 \mathrm{~kg} \cdot \mathrm{cm}^{-}$.

$=2.1 \times 10^{5} \mathrm{Mpa}$.

- Tiang Pancang

Tiang pancang yang direncanakan pada dermaga Island Berth ini adalah tiang pancang baja JIS A 5525 dengan spesifikasi sebagai berikut :

- Material type

$=$ steel

- $\quad$ Outside diameter (OD)

- Thickness (t)

$=1016,0 \mathrm{~mm}$

$=19 \mathrm{~mm}$

$=457 \mathrm{~kg} / \mathrm{m}$

Weight (W)

$=595,10 \mathrm{~cm}^{2}$

- Area of Cross Section (A)

- $\quad$ Moment of Inertia (I)

$=740 \times 10^{3} \mathrm{~cm}^{4}$ 
- $\quad$ Section Modulus

- $\quad$ Radius of Gyration (r)

- Young Modulus (E)

- $\quad$ Area of Outer Surface (fu)

$$
\begin{aligned}
& =146 \times 10^{2} \mathrm{~cm}^{3} \\
& =35,20 \mathrm{~cm} \\
& =2100000 \mathrm{~kg} / \mathrm{cm}^{2} \\
& =3,19 \mathrm{~m}^{2} / \mathrm{m}
\end{aligned}
$$

3. Kriteria alat

Marine Loading Arm (MLA), Gangway, Jib Crane, Fire Monitor Tower, Tug Boat

4. Pembebanan

\subsection{Pembebanan vertikal}

1. Beban mati ( beban sendiri konstruksi )
a. Berat jenis $(\gamma)$ beton bertulang
b. Berat jenis $(\gamma)$ baja profil

$$
\begin{aligned}
& =2900 \mathrm{Kg} / \mathrm{m}^{3} \\
& =7850 \mathrm{Kg} / \mathrm{m}^{3} \\
& =3 \mathrm{t} / \mathrm{m}^{2} \\
& =0.05 \mathrm{t} / \mathrm{m}^{2} \\
& =5 \mathrm{kPa}(\text { SNI T-02-2005) }
\end{aligned}
$$$$
=3 \mathrm{t} / \mathrm{m}^{2}
$$
a. Beban merata akibat beban pangkalan
b. Beban air hujan $(5 \mathrm{~cm})=0.05 \times 1 \mathrm{t} / \mathrm{m}^{2}$
$=5 \mathrm{kPa}(\mathrm{SNI} \mathrm{T}-02-2005)$

\section{Beban terpusat}

a. Beban pipa yang melintasi loading platform dengan diameter 12 inch sebesar 73,86 Kg/m ( API 5L spesification for erw steel pipes )

b. Beban cairan yang akan disalurkan melalui pipa adalah $\pi \mathrm{x} \mathrm{r}^{2} \times y_{\text {minyak }}=3.14 \times 0.0 .1619^{2} \times 800=58343 \mathrm{Kg} / \mathrm{m}$

c. Beban dari MLA ( Marine Loading Arm ), berdasarkan Tabel 5.1 beban terpusat dari alat tersebut adalah $340 \mathrm{kN}$

d. Beban dari Gangway, berdasarkan Spesifikasi Lexxon Gangway Column ( LX02) beban terpusat diambil 27 ton

e. Beban Jib crane adalah beban terpusat dengan berat $4500 \mathrm{~kg}$

f. Beban fire monitor tower adalah beban terpusat dengan berat $1675 \mathrm{~kg}$

\section{Beban akibat gempa}

Beban akibat gempa, diambil dari web puskim.co.id kemudian penentuan gaya gempa diperhitungan dengan menggunakan program bantu SAP 2000 dengan menggunkan respon spektra menurut SNI 03-1726-2012

\subsection{Pembebanan horizontal}

a. Gaya tumbukan kapal (fender)

b. Gaya tarikan kapal (bollard)

\section{Perencanaan Fender}

Untuk menentukan kebutuhan fender perlu memperhatikan beberapa aspek, yaitu : kecepatan kapal saat merapat dan ukuran kapal yang direncanakan dimana kecepatan ini akan berpengaruh pada besarnya energi kinetik yang akan diabsorbsi oleh fender dan dialirkan menjadi beban horizontal. Perlu di perhatikan pula pemilihan tipe fender yang tepat agar dapat melayani kapal yang bersandar dengan baik [3].

Adapun rumusan dalam menghitung energi kinetik mengacu pada brosur PIANC 2002[4]. Pada perencanaan dermaga Island Berth ini direncanakan dapat ditambati kapal oil tanker 85.000 DWT menggunakan breasting dolphin, sehingga untuk menentukan energi kinetik bertambat normal $\left(E_{N}\right)$ digunakan rumusan :

$$
E f=0,5 x M D x(V b)^{2} x C M x C E x C S x C C
$$

Dari perhitungan energi fender diperoleh $\mathrm{Ef}_{\text {akhir }}=1068,9 \mathrm{kNm}$ maka direncanakan fender dengan jenis Super Cone Fender (SCN) Tipe SCN 1400 E1.2,dengan spesifikasi pada tabel 2.2:

Tabel 2.2 - Spesifikasi Fender

\begin{tabular}{lllllll}
\hline Jenis Fender & Energi & Reaksi & Berat & Diameter & Dimensi Frontal Pad & Berat Frontal Pad \\
\hline SCN 1400 E 1.2 & $1085 \mathrm{kNm}$ & 1498 & $3105 \mathrm{~kg}$ & $2,24 \mathrm{~m}$ & $2,5 \times 4 \times 3 \mathrm{~m}$ & $3000 \mathrm{~kg}$ \\
\hline
\end{tabular}

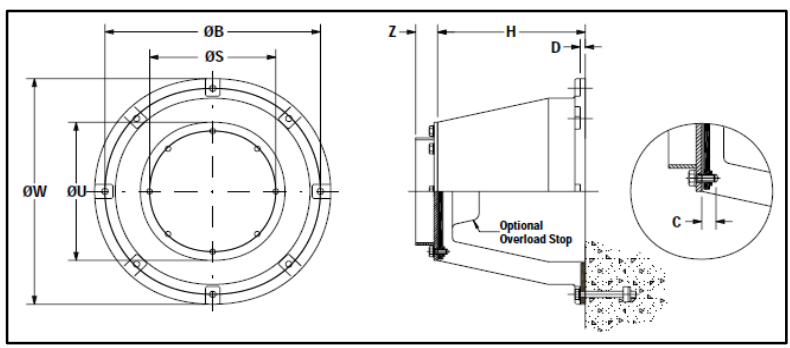

Gambar 2.8 - Spesifikasi Fender (Sumber : Brosur Trelleborg) 


\section{Perencanaan Bollard}

Kapal yang direncanakan untuk bertambat pada dermaga ini memilik kapasitas 85.000 DWT. Gaya tarik akibat kapal diambil sebesar Minimum Breaking Line (MBL) tali pada kapal yang ditinjau[5]. Apabila dibandingkan dengan gaya tarikan kapal maka gaya yang dipakai untuk perencanaan dipilih gaya tarik kapal 200 ton berdasarkan bobot kapal. Dalam merencanakan bollard pada konstruksi dermaga Island Berth ini diganakan bollard tipe Quick Release dengan double hooks. Digunakan QRH double hook produk Mampaey dengan type MHC.000.100.402 dengan kemampuan SWL $1000 \mathrm{kN}>874,5 \mathrm{kN}$, dan kemampuan PL $2000 \mathrm{kN}>1705,275 \mathrm{kN}$

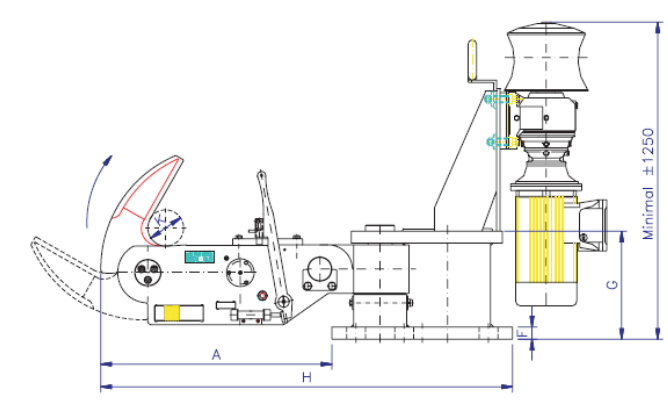

Gambar 2.9 - Spesifikasi Quick Release Hook ( Sumber : Mampaey QRH Catalogue)

\subsection{Perhitungan Struktur}

Dari hasil perhitungan didapatkan nilai untuk struktur dermaga sebagai berikut:

1. Catwalk

- Bantalan catwalk
a. Dimensi
b. Tulangan tarik dan tekan (arah X)
c. Tulangan tarik dan tekan ( $\operatorname{arah} \mathrm{Y})$
d. Tulangan samping $\operatorname{arah} \mathrm{X}$ dan $\mathrm{Y}$

$=300 \times 150 \times 100 \mathrm{~cm}$

$=15 \mathrm{D} 22$

$=6 \mathrm{D} 22$

$=2 \mathrm{D} 22$

- Tiang pancang

a. Data tiang pancang

b. Kedalaman tiang tegak

$=1016,0 \mathrm{~mm} \mathrm{t}=19 \mathrm{~mm}$

$=-13,5 \mathrm{~m}$ dari seabed

2. Mooring dolphin

a. Spec.Steel pile

b. Kedalaman tiang miring

c. Penulangan poer

Tulangan tarik dan tekan $(\operatorname{arah} X)$

$=$ Steel pipe pile $\emptyset 1016,0 \mathrm{~mm} \mathrm{t}=19 \mathrm{~mm}$

$=-22 \mathrm{~m}$ dari seabed

Tulangan tarik dan tekan (arah Y)

$=\mathrm{D} 25-170$

$=\mathrm{D} 25-170$

Tulangan samping arah $\mathrm{X}$ dan $\mathrm{Y}$

$=\mathrm{D} 25-350$

3. Breasting dolphin

a. Spec.Steel pile

b. Kedalaman tiang miring

c. Penulangan poer

Tulangan tarik dan tekan $(\operatorname{arah} X)$

$=$ Steel pipe pile $\emptyset 1016,0 \mathrm{~mm} \mathrm{t}=19 \mathrm{~mm}$

$=-28 \mathrm{~m}$ dari seabed

Tulangan tarik dan tekan (arah Y)

$=\mathrm{D} 32-75$

$=\mathrm{D} 32-75$

Tulangan samping arah $\mathrm{X}$ dan $\mathrm{Y}$

$=\mathrm{D} 16-88$

d. Penulangan balok fender

Tulangan tarik dan tekan $(\operatorname{arah} X)$

$=10 \mathrm{D} 16$

$=10 \mathrm{D} 16$

$=2 \mathrm{D} 16$

Tulangan samping arah $X$ dan $Y$

$=\varnothing 1016 \mathrm{~mm}, \mathrm{t}=19 \mathrm{~mm}$

a. Spec.Steel pile

b. Penulangan pelat

Tulangan tarik arah $\mathrm{x}$

$=\mathrm{D} 16-100$ 
Tulangan tekan arah $\mathrm{x}$

Tulangan tarik arah y

Tulangan tekan arah y

- $\quad$ Balok Melintang $75 \mathrm{~cm}$ x $90 \mathrm{~cm}$

Tulangan Tumpuan Tarik

Tulangan Lapangan Tarik

Tulangan Samping

- $\quad$ Balok Memanjang $75 \mathrm{~cm}$ x $90 \mathrm{~cm}$

Tulangan Tumpuan Tarik

Tulangan Lapangan Tarik

Tulangan Samping

c. Penulangan poer tunggal

Tulangan tarik dan tekan (arah X)

Tulangan tarik dan tekan (arah Y)

Tulangan samping arah X dan Y
$=\mathrm{D} 16-80$

$=\mathrm{D} 16-200$

$=\mathrm{D} 16-200$

$=6 \mathrm{D} 32$

$=6 \mathrm{D} 32$

$=2 \mathrm{D} 32$

$=4 \mathrm{D} 32$

$=4 \mathrm{D} 32$

$=2 \mathrm{D} 32$

$=15 \mathrm{D} 32$

$=19 \mathrm{D} 32$

$=4 \mathrm{D} 25$

\subsection{Metode Pelaksanaan}

Dalam bab ini akan dibahas bagaimana merencanakan sebuah metode pelaksanaan pekerjaan yang akan dilakukan pada pembangunan dermaga Island Berth dengan rincian :

1. Struktur dermaga yang meliputi, loading platform, mooring dolphin, dan breasting dophin.

2. Struktur catwalk

3. Struktur floating pontoon

Dalam pelaksanan struktur jetty, perencanaan dibagi menjadi 3 tahap :

a. Tahap prakonstruksi/persiapan

b. Tahap konstruksi

c. Tahap pasca kontruksi

Pada tahapan konstruksi ini pekejaan yang dapat dilakukan adalah sebagai berikut :
a. Pekerjaan tiang pacang
b. Pekerjaan beton ( balok, poer dan pelat )
c. Pekerjaan fasilitas dermaga

\subsection{Kesimpulan}

1. Spesifikasi Kapal Rencana
a. DWT
$:=85000$ ton
b. Displacement Tonnage
$=120000$ ton
c. GT
d. LOA
$=47050$ ton
e. Lbp
$=242 \mathrm{~m}$
f. Width
$=230 \mathrm{~m}$
$=35,4 \mathrm{~m}$
g. Full Draft
h. Light Draft
$=12,92 \mathrm{~m}$
$=4,27 \mathrm{~m}$
i. Height
$=20,12 \mathrm{~m}$
j. Capacity
$=133024 \mathrm{~m}^{3}$

2. Struktur jetty yang direncanakan terdiri dari loading platform, breasting dolphin, mooring dolphin, catwalk, dan Floating Pontoon

3. Struktur Loading Platform direncanakan beton bertulang konvensional dengan spesifikasi :
a. Dimensi struktur
b. Dimensi balok melintang
c. Dimensi balok memanjang
d. Selimut beton
e. Tebal pelat
f. Mutu beton
g. Mutu baja
h. Tulangan pelat
i. Tulangan lentur
j. Tulangan geser
k. Pile cap tunggal
1. Tiang pancang
m. Kemiringan tiang

$=35,5 \times 24 \mathrm{~m}$

$=75 \times 90 \mathrm{~cm}$

$=75 \times 90 \mathrm{~cm}$

$=8 \mathrm{~cm}$

$=30 \mathrm{~cm}$

$=\mathrm{K} 350$

$=\mathrm{U} 32$

=D 16

$=\mathrm{D} 32$

$=\varnothing 22$

$=200 \times 200 \times 100 \mathrm{~cm}$

$=\emptyset 1016 \mathrm{~mm}, \mathrm{t}=19 \mathrm{~mm}$

$=6: 1$ 

n. Kedalaman tiang tegak
$=-25 \mathrm{mLWS}$
o. Panjang tiang tegak
$=28 \mathrm{~m}$
p. Kedalaman tiang miring
$=-40 \mathrm{mLWS}$
q. Panjang tiang miring
$=40 \mathrm{~m}$

4. Struktur Breasting Dolphin direncanakan beton bertulang konvensional dengan spesifikasi :
a. Dimensi struktur
$=8 \times 8 \mathrm{~m}$
b. Selimut beton
$=8 \mathrm{~cm}$
c. Tebal poer
d. Mutu beton
$=2 \mathrm{~m}$
e. Mutu baja
$=\mathrm{K} 350$
f. Tulangan lentur
$=\mathrm{U} 32$
g. Tiang pancang
$=\mathrm{D} 32$
h. Kemiringan tiang
$=\emptyset 1016 \mathrm{~mm}, \mathrm{t}=19 \mathrm{~mm}$
i. Kedalaman tiang
$=6: 1$
j. Panjang tiang
$=-57 \mathrm{mLWS}$
$=60 \mathrm{~m}$

5. Struktur Mooring Dolphin direncanakan beton bertulang konvensional dengan spesifikasi :
a. Dimensi struktur
$=6,5 \times 6,5 \mathrm{~m}$
b. Selimut beton
$=8 \mathrm{~cm}$
c. Tebal poer
$=2 \mathrm{~m}$
d. Mutu beton
$=\mathrm{K} 350$
e. Mutu baja
$=\mathrm{U} 32$
f. Tulangan lentur
$=\mathrm{D} 32$
g. Tiang pancang
h. Kemiringan tiang
$=\emptyset 1016 \mathrm{~mm}, \mathrm{t}=19 \mathrm{~mm}$
i. Kedalaman tiang
$=6: 1$
$=-59 \mathrm{mLWS}$
j. Panjang tiang
$=60 \mathrm{~m}$

6. Struktur Catwalk direncanakan sebagai struktur baja circular hollow section dengan spesifikasi :
a. Bentang struktur
$=24,28$, dan $30 \mathrm{~m}$
b. Dimensi balok utama
c. Lebar pelat
d. Tinggi rangka
$=$ CHS $219 \times 10$
$=2 \mathrm{~m}$
$=1,5 \mathrm{~m}$

7. Struktur Floating Pontoon direncanakan menggunakan box pontoon yang terbuat dari HDPE dengan pengaku Stainless steel Galvanised dengan spesifikasi :
a. Luas
b. Tiang pancang
$=625 \mathrm{~m}^{2}$
c. Tiang pancang
d. Draft
$=\emptyset 1016 \mathrm{~mm}, \mathrm{t}=19 \mathrm{~mm}$
$=50 \mathrm{~mm}, \mathrm{t}=19 \mathrm{~mm}$
$=58,38$

8. Dalam pelaksanaan konstruksi dermaga Island Berth ini, Direksi kit yang digunakan berada diatas kapal pontoon, hal ini dikarenakan lokasi proyek yang berada ditengah laut. Sehingga digunakan direksi kit ini untuk mempermudah koordinasi dan pelaksanaan proyek dilapangan. Selain itu, dibangun temporary jetty yang berlokasi di garis pantai yang berjarak $357 \mathrm{~m}$ dari area proyek yang menghubungkan antara area penumpukan material dan lokasi proyek untuk memudahkan mobilisasi dan demobilisasi pekerja, alat, maupun material. Sistem keamanan dan keselamatan yang digunakan dalam proyek ini adalah sistem yang telah berstandar ISO serta tenaga yang digunakan dalam pekerjaan proyek ini sudah bersertifikat resmi. Suatu proyek dengan metode sistematis dan terstruktur dapat menekan kemungkinan terjadinya keterlambatan durasi proyek dan angka kecelakaan dalam pekerjaan proyek Dermaga Island Berth untuk kapal tanker 85000 di area offshore PT Badak NGL, Bontang ini.

\section{Daftar Pustaka}

[1] J. P. and H. Association, Technical Standards and Commentaries for Port and Harbour Facilities in Japan. Japan: Daicousa Printing, 2002.

[2] H. Wahyudi, Daya Dukung Pondasi Dalam. Surabaya: Jurusan Teknik Sipil Fakultas Teknik Sipil dan Perencanaan ITS., 2013.

[3] D. I. Widyastuti, Diktat Pelabuhan. Surabaya: Jurusan Teknik Sipil Fakultas Teknik Sipil dan Perencanaan ITS, 2000.

[4] PIANC, Guidelines for the design of fenders systems. 2002.

[5] C. A. Thoresen, Port designer's handbook. British: Thomas Telford, 2003. 